УДК 811.111: 371.3

DOI: 10.17277/voprosy.2016.01.pp.147-152

\title{
ENGLISH FOR ACADEMIC PURPOSES IN HIGHER EDUCATION CURRICULUM
}

\author{
E. V. Dvoretskaya
}

Tambov State Technical University, Tambov

Reviewed by Doctor of Pedagogic Sciences, Professor R. P. Milrood

Keywords: academic competence; communicative competence; English as a Foreign Language; English for Academic Purposes; university curriculum.

Abstract: The paper discusses the organization of English as a Foreign Language curriculum in Russian higher education, its objectives and key competences it develops. It is argued that the focus of a university English language teaching should be on developing academic competence of students, accommodating for the fulfillment of study objectives involving the use of English and preparing them for international exchanges and independent work with English-language resources. This can be achieved by setting English for Academic Purposes as a core module of the university EFL curriculum.

\section{Introduction}

Should English for Academic Purposes (EAP) be at the core of a university language curriculum? At a glance, this question may seem paradoxical. There exists most close correspondence between EAP and academic studies. However, if we carefully examine the traditions of EFL teaching in Russian higher educational institutions and - which is more important - federal standards for language studies, we will see that EAP is merely one of the modules and usually not the most significant and lengthy in the university EFL curriculum.

Russian participation in international educational area is characterized by intensive development of international academic mobility schemes, setting up of international joint and double degree programs and active introduction of English as a language of instruction into various degree programs in Russian universities. Although the overall number of students participating in international academic mobility is not high for a country like Russia - according to the latest research, about 72,000 students a year go abroad for both short and long-term periods of study - the trend is on the move (Report of the Center for Innovative Educational System Development of Lomonosov Moscow State

Дворецкая Екатерина Валерьевна - кандидат филологических наук, доцент кафедры «Международная профессиональная и научная коммуникация», e-mail: dvkaterina@yandex.ru, ТамбГТУ, г. Тамбов.

УНИВЕРСИТЕТ им. В.И. ВЕРНАДСКОГО. №1(59). 2016. 
University, 2007) [1]. More and more courses and full programs of studies at undergraduate and postgraduate levels are designed in English. While, as worldwide, their "prime audience" is international students, these courses are becoming popular with Russian students as well, particularly with those who foresee a period of international study or plan to work abroad after the graduation.

Researchers often debate the quality of English-medium programs offered in non-English-speaking countries, by non-native speakers of English. It must be noted that in case of Russia, such programs tend to be an elite product. They exist mainly in large, renowned universities, often in partnership with a wellestablished international school, and their names - and usually an independent quality assurance exercise and/or accreditation - guarantee their quality. This, for example, is the case of Plekhanov International Business School, which is listed among the top 30 Russian business schools and which programs are accredited by the European Council for Business Education (ECBE). This school, now a faculty of the Plekhanov Russian University of Economics, has been offering double-degree business education in English since 1992.

More common, however, are the programs which combine Russian and English-medium education, the so-called bilingual programs. For example, Tambov State Technical University has been providing bilingual (Russian and English) studies since 2005 as an additional module within several of its undergraduate programs in engineering and economics [2]. These are in good demand among Russian students as they allow to master English language in professional context, they prepare for and give opportunity to study abroad and, at the same time they are less stressful for students in terms of language requirements because at least part of the program can be studied in a native language.

Having said this, we have accepted one basic concept - it IS difficult to study in a university in a foreign language. Apparently, it is impossible to compare the degree to which English-language instruction influences students' academic successes: different students put different amount of effort into their studies, be they in a native or in a foreign language. Some studies [3] even show that students may perform better in English than their peers perform in the mother tongue, although this may be due to high selection for English-medium programs. Generally, studying in English is as much an additional complexity for students as it is a benefit. And the challenge is not only pure language knowledge, quite often the whole paradigm of organization of studies is different depending on what language of instruction is used. And this means that students must be well-prepared before or at least simultaneously with starting an English-medium course of study. How can comprehensive university-level language teaching help them?

\section{EFL curriculum in Russian universities}

The Russian system of education is heavily regulated by federal educational standards which are developed by the Ministry of Education and Science and are to be implemented in all educational institutions accredited by it. Nevertheless, the foreign language curriculum for non-language studies is not specified by these standards. Students are generally required to master one foreign language (in most cases they can choose from English, German and French) for a certain amount of contact hours. The exact number of hours and credits varies from one university to another but it cannot be less than what 
is stated in federal standards. As to what exactly should be taught, universities are advised to follow a model syllabus designed by the Methodology Research Council on Foreign Languages of the Ministry of Education (latest edition 2010).

According to this syllabus the main aim of FLT in universities is developing a sufficient level of foreign language communicative competence for social interaction with speakers of other languages in a variety of professional, academic, cultural and social settings. Communicative competence presupposes development of linguistic, sociolinguistic, pragmatic competences and the knowledge of discourse, which combined will result in meaningful and productive communication in a foreign language.

The FL course is recommended to include four modules: 1) general language (speaking of English, it is General English course) - to ensure the knowledge of base vocabulary, develop general listening, speaking and writing skills; 2) language for specific purposes (ESP in our case) - fields vary according to the area of studies; 3) language for business (Business English) - within modules 2 and 3 students are expected to learn and develop those skills and knowledge which are essential for their future professional activity, acquire general and specialized vocabulary of their profession, develop listening comprehension and speaking skills in relation to professional context, master professionally relevant discourse and learn useful business communication skills and strategies in a foreign language; 4) language for academic purposes EAP.

In recent decades, together with building general communicative competence, the emphasis has been on the development of intercultural communication skills, and intercultural competence of university graduates those knowledge, skills and attitudes that comprise a person's ability to get along with, work and learn with people from diverse cultures - is also considered to be a key competence in foreign language teaching.

However, even more topical for students is the development of academic competence in a foreign language. First of all, it refers to the ability to distinguish between formal and informal, and specifically, academic and colloquial styles of language. All pre-university language learning falls into the category of mastering general language, with only a few, so-called "specialised linguistic" secondary schools offering courses in, for example, Business English and/or English for Science. The majority of secondary school graduates fail to recognize different registers in English, leaving aside the ability to engage in stylistically appropriate communication. Besides, even a good degree of linguistic confidence in everyday conversation and situations does not ensure the ability to cope with cognitively and linguistically demanding academic materials. To use distinctions proposed by Cummins [4], students' basic interpersonal communication skills (BICS) might be adequate, while their cognitive academic language proficiency (CALP) leaves much to be desired.

Development of CALP or academic competence in English is absolutely indispensable for nowadays students as English has de facto become "modern Latin", the language of science. Productive study cannot be imagined without independent research and work with up-to-date resources in English. This is most certainly true for students of bilingual programs who need to research, analyse and integrate knowledge and information from a variety of sources in English in order to carry out their studies. Thus, the aim of a university EAP course must be to accommodate for the fulfillment of study objectives involving the use of English. 


\section{EAP course components}

Being a branch of ESP, English for Academic Purposes strives to explicitly match teaching content to the language and study needs of the learners. Thus, components of an EAP course should reflect the essence of university studies: they imitate types of tasks and activities students perform and develop linguistic skills and cognitive strategies needed to operate with complex matter. Researchers universally agree - and analysis of a number of published EAP textbooks proves it (Cambridge Academic English by Cambridge University Press, EAP Now! by Pearson Education, Oxford EAP by Oxford University Press, among others) - that the most "demanded" areas for students who study through the medium of English are academic reading, writing and listening [3, 5]. Each of them involves specific language knowledge and implies development of transferable cognitive skills that allow a student to succeed in an academic context.

It should be mentioned that EAP has two divisions: English for General Academic Purposes (EGAP) and English for Specific Academic Purposes (ESAP). EGAP focuses more on common core study skills, while ESAP is more subject-specific, including language structures, vocabulary and academic conventions appropriate for a particular discipline, for example, science or economics [5, p. 4-5]. In this article we shall not distinguish between these two varieties, keeping in mind, however, that a necessary degree of specialisation of the EAP course can easily be achieved through implementation of ESAP elements.

Academic reading can be considered a central area of language use for university students. And a key element of successful reading ability is massive vocabulary that is rapidly and accurately processed. Secondly, fluent reading presupposes automatic recognition of relevant grammatical information. Thus, the ability to read fluently in English significantly relies on the general level of proficiency in the language, and EAP classes should aim at developing and extending students' knowledge of English grammar and vocabulary. However, no less important for the understanding of academic texts - and therefore for successful academic performance - is development of students' abilities to read strategically, to analyse and comprehend text structure and register, to interpret and classify information from the text, i.e. their CALP skills. In fact, Hellekjaer (2006) argues that the level of academic reading proficiency to a large extent determines successful acquisition of cognitive academic language proficiency in general [6].

The most problematic use of English in tertiary education is probably writing. Writing tasks vary from writing short answers in examinations to writing essays, reports, dissertations, theses, journal articles. The purpose of the EAP course is to enable students to express themselves coherently and in an appropriate formal style and provide examples of good academic writing. This area of EAP is especially significant for Russian students as Russian and English academic writing traditions differ in many respects. When preparing to undertake a period of study in an English-medium university, students need to acquire knowledge of the format and language of examination essays and other forms of written assessment. 
One more aspect of language students tend to worry about is academic listening comprehension, particularly listening to lectures. Note-taking is a skill closely related to it, thus, listening comprehension and note-taking are usually covered together in an EAP course. To fully understand lectures in English and, subsequently, fully benefit from education delivered through the medium of English, students need to be aware of the way lectures are organised and what particular kind of language is used in lectures. They should be able to understand relations in the lecture (what the main and subsidiary points are), to "read signposts", to develop their ability to deduce the meaning of unfamiliar words from context and to recognise implications (which information is not explicitly stated, what the speaker's attitude is, etc.). While listening, students will master relevant academic skills - taking notes, skimming (listening to obtain gist), scanning (listening to obtain specific information), summarizing texts.

\section{Conclusion}

Extensive development of academic mobility and bilingual degree programs in Russian universities have put a special emphasis on the role of ELT in the university curriculum and have called out for new approaches to successful language learning. Accepting English for Academic Purposes as a core module of a university English language course is one of the solutions proposed by a number of Russian universities.

As Hutchinson and Waters point out, "the fact that language is used for a specific (in our case, academic - E. D.) purpose does not imply that it is a special form of a language, different in kind from other forms" [7, p. 18]. Building a university EFL curriculum in an EAP-oriented way does not discard mastering other, more general language skills. However, it can allow to develop those competences that are indispensable for academic study. First of all, it is critical thinking and problem-solving skills in direct correlation with disciplinespecific information and knowledge. Secondly, through EAP course students may develop their research and information management skills through searching and evaluating materials in English, learning to interpret and report on research, share knowledge, network and work in teams, etc. Communicative tasks meant to build social communicative skills can be set around academic-related texts and materials. Thus, changing the focus of a university English language teaching to EAP will provide both for the acquisition of general linguistic and sociolinguistic skills in English and for the development of academic competence necessary to carry out study and research both in a home country and during study abroad.

\section{References}

1. Formirovanie sistemy innovatsionnogo obrazovaniya $v$ MGU im. M.V. Lomonosova [Formation of innovative education system in the Moscow State University. M.V.Lomonosov], 2007, available at: http://inpro.msu.ru/PDF/ opyt_vuzov.pdf (accessed 16 April 2015). (In Russ.)

2. Dvoretskaya E.V., Mischenko E.S., Dvoretsky S.I. Proceedings of the $37^{\text {th }}$ International IGIP Symposium "Engineering competencies - traditions and innovations”, Moscow, 2008, p. 173-174.

3. Hommes J., Muysken J. Paper given at 8th EDINEB Congress, Nice, 20-22 June, 2001.

4. Cummins J., Swain M. Bilingualism in education: Aspects of theory, research and policy, London: Longman, 1986, 235 p. 
5. Jordan R.R. English for Academic Purposes: A guide and resource book for teachers, Cambridge: Cambridge University Press, 1997, 404 p.

6. Hellekjaer G.O. Screening criteria for English-medium programmes: a case study, Bochum: AKS-Verlag, 2006, p. 43-60.

7. Hutchinson T., Waters A. English for Specific Purposes: A learning-centred approach, Cambridge: Cambridge University Press, 1987, 192 p.

\section{Список литературы}

1. Опыт российских вузов по созданию и реализации различных моделей образовательных программ [Электронный ресурс] // Формирование системы инновационного образования в МГУ им. М.В. Ломоносова, 2007. - Режим доступа : http://inpro.msu.ru/PDF/opyt_vuzov.pdf (дата обращения : 16.04.2015).

2. Dvoretskaya, E. V. Bilingual Programmes as a New Dimension of Engineering Education in Russia. / E. V. Dvoretskaya, E. S. Mischenko, S. I. Dvoretsky // Proceedings of the $37^{\text {th }}$ International IGIP Symposium «Engineering Competencies Traditions and Innovations». - Moscow, 2008. - P. $173-174$.

3. Hommes, J. Structured Peer Review in Writing Skills in Economics / J. Hommes, J. Muysken // $8^{\text {th }}$ EDINEB Congress, Nice, 20 - 22 June, 2001.

4. Cummins, J. Bilingualism in Education: Aspects of Theory, Research and Policy / J. Cummins, M Swain. - London : Longman. - 1986. - 235 p.

5. Jordan, R. R. English for Academic Purposes: A Guide and Resource Book for Teachers / R. R. Jordan. - Cambridge : Cambridge University Press. - 1997. - 404 p.

6. Hellekjaer, G. O. Screening Criteria for English-Medium Programmes: a Case Study / G. O. Hellekjaer // Bridging the Assessment Gap in English-Medium Higher Education. - Ed. by R. Wilkinson, V. Zegers and C. van Leeuwen. - Bochum : AKSVerlag, 2006. - P. $43-60$.

7. Hutchinson, T. English for Specific Purposes: a Learning-Centred Approach / T. Hutchinson, A. Waters. - Cambridge : Cambridge University Press. $-1987 .-192$ p.

\section{Английский язык для академических целей в программе высшего профессионального образования}

\section{Е. В. Дворецкая}

\section{ФГБОУ ВПО «Тамбовский государственный технический университет», г. Тамбов}

Ключевые слова: академическая компетенция; английский язык для академических целей; английский язык как иностранный; коммуникативная компетенция; программа высшего профессионального образования.

Аннотация: Рассмотрены организация преподавания английского языка как иностранного в российской системе высшего профессионального образования, цели обучения английскому языку и ключевые развиваемые компетенции. Основной целью преподавания английского языка в вузе является развитие академической компетенции студентов, то есть подготовка студента к использованию иностранного языка в своей учебной деятельности, самостоятельной работе с англоязычными учебными ресурсами и участию в международных образовательных обменах. Таким образом, ключевым модулем в университетском курсе английского языка должен стать курс английского языка для академических целей. 